\title{
THE CONCEPT OF "SALA DE FABRICA": ON-SITE MUSEUMS TO RAISE AWARENESS OF CULTURAL HERITAGE AFTER A RESTORATION PROJECT
}

\author{
Ana ALMAGRO VIDAL ${ }^{1}$, Teresa BLANCO TORRES ${ }^{\mathbf{1}}$, Gabriel MORATE MARTÍN ${ }^{1}$ \\ ${ }^{1}$ Programa de Conservación del Patrimonio Histórico Español, Fundación Caja Madrid \\ Plaza de San Martín, 1 - Madrid (Spain) \\ aalmagro@cajamadrid.es, tblancot@cajamadrid.es, gmoratem@cajamadrid.es
}

Keywords: restoration project, documentation, communication, museum, visualization of cultural heritage

\begin{abstract}
A conservation process usually generates new knowledge and an enormous amount of documentation during the inception and implementation of the project: the information collected from archives and other institutions; the information provided by the preliminary studies carried out prior to the intervention; the data provided in the field during the works and at the end of the process; and the final set of documentation delivered to the institution responsible for the maintenance and management of the monument. The challenge for conservation professionals and cultural heritage managers throughout this process once the works are over is to achieve and transmit this information to the public and specialists in order to raise awareness for better conservation of our built heritage. During the last few years, one of the actions that the Caja Madrid Foundation has activated with its restoration projects has been the opening of permanent on site museums or "Salas de Fábrica", a place on site to understand the restoration works, to exhibit the remains that have being retrieved during the project and to permit the public to better understand the historical and artistic values of architectural and archaeological heritage as well as the importance of preserving our cultural legacy for the future.
\end{abstract}

\section{COMMUNICATION AND DISSEMINATION AS PART OF A RESTORATION PROJECT}

Traditionally, intellectual, technical and financial efforts in heritage conservation have always, except for a few exceptions, focused on the restoration of the monument. In these projects communication and dissemination actions were considered as external activities apart from the restoration project and/or in any case, after the restoration process. This situation has not taken advantage of the enormous capacity of knowledge, public awareness, and enjoyment that a restoration project can offer. The development of a restoration project is a knowledge process and continuous learning that in most cases implies a critical review and deeper understanding of what had been known up to the present. The transmission of this knowledge to society, especially that community of which the monument forms a part, is of great importance for the appreciation and conservation of the monument. Plus, the restoration is a perfect time to understand patrimony's documentary value and the fact that it can be constantly re-interpreted, something that will not end with the intervention. Cultural dissemination of a restoration project should clearly show the scientific, technical and financial complexity of restoration projects in general. This is key with regards to a more participative and critical consciousness about the actions undertaken with respect to our historical heritage. It is understood that raising society's awareness about the problems affecting the preservation of heritage and about the capacity to solve them promotes attitudes of greater responsibility. The comprehensive preservation of a monument implies taking into account not only its material aspect but also its future management and use for tourism. It is clear, therefore, that from the beginning the restoration

\footnotetext{
${ }^{1}$ It is important to mention the authors' difficulties when trying to translate the concept of "Sala de Fábrica" into English. It was finally decided to leave it in Spanish so as to keep the concept intact. Even if the first experiences creating "Salas de Fábrica" are mentioned throughout the paper as on-site museums it is important to highlight that they are, in fact, not museums. The official and widely understood definition of a museum is an institution with logistic and management support needed for maintainance; while a "Sala de Fábrica", once it is opened to the public, does not need anything but the monument itself. It can be explained without any external help and is completely self-sustainable.
} 
project should involve society and managers, with a sense of their responsibility after the works in terms of guaranteeing the feasibility and sustainability of public access to the monument, not only during the works but also once these are over. To this end, it is fundamental in restoration projects promoted by the Caja Madrid Foundation, to consider Communication and Dissemination Plans as one important chapter of the intervention, being always defined and developed according to the magnitude of the intervention and the characteristics of the monument. These plans entail a series of actions carried out during the restoration work and once the project concludes, aimed to strengthen the monument's cultural value and significance. Along with dissemination activities such as on-site communication, didactic workshops for young children and monthly video diffusion of the restoration progress on the internet, one of the most significant actions of these plans is being directed toward the installation of on-site museums, as a specific space inside the monument to promote the public familiarity with heritage sites and raise awareness about the importance of preserving them after these projects are finished.

\section{FIRST EXPERIENCES WITH THE ON-SITE MUSEUMS}

Since the creation of the Spanish Historic Heritage Conservation Department at the Caja Madrid Foundation in 1996 , the first actions that were promoted were to simply inform the public through the installation of graphic panels on site about the monument values and its significance as well as the ongoing restoration works, in order to raise awareness about the problems and efforts that heritage conservation requires [1]. When circumstances were appropriate, the actions turned to prepare a small space in the restored monument so as to permanently exhibit the most relevant documentation produced during the intervention, mainly the results of the historical and documentary research as well as the works or archaeological excavations carried out in the framework of the project, aimed to implement the exhaustive knowledge of the building. This is the case of the project at Santa Cueva in Cádiz where, during the restoration of the Crypt, liturgical items of high artistic value were retrieved. It was decided to restore and exhibit them in a space available above the crypt and explain the complexity of the space, something that had never been done before. The next case was at the Convent of San Agustín in Talavera de la Reina, where a small space was dedicated to life and work of Fray Lorenzo de San Nicolás, the Convent architect, and distinguished essayist of the $17^{\text {th }}$ century. Finally, at the church of Santa Catalina in Valencia, tombstones and a sculpture of a bishop's head were discovered inserted in the fabric of the façade, in a medieval arcosolio (a burial niche). These were then displayed on site with explanations concerning their discovery and historic context (Figure 1).

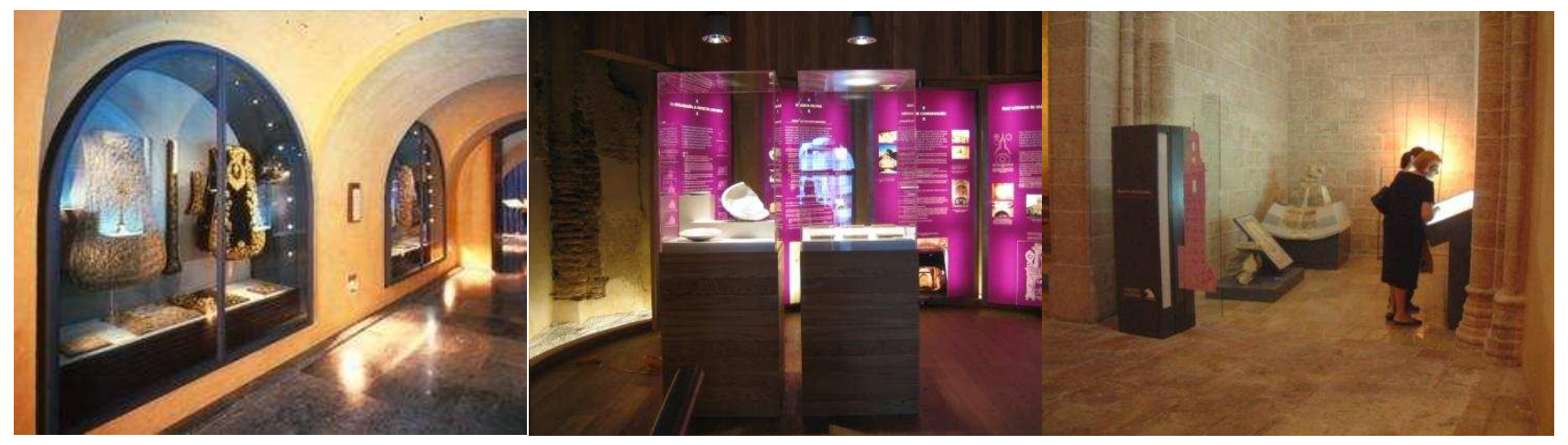

Figure 1. First experiences in Santa Cueva (Cádiz), San Agustín (Talavera de la Reina) and Santa Catalina (Valencia)

It was decided during these restoration projects to take advantage of three fortuitous circumstances, not predictable a priori:

- Lack of space or elements dedicated to explaining the significance and importance of the monument.

- Abandoned pieces of great artistic value, some already existing and some retrieved during the restoration project. 
- Existence of an available space where, with the property permission, it was possible to exhibit and explain the objects, the monument and the importance of preserving them.

The success of these first experiences demonstrates the usefulness of permanent on-site dissemination. This permits visitors to have a better understanding of the monument and the conservation process.

\section{THE CULTURAL RESTORATION PROJECTS}

Since these experiences, increasing importance has been given to the social and economic dimension of projects and their dissemination. These projects, promoted by the Caja Madrid Foundation, are now defined as "Cultural Restoration Projects". They seek a qualitative and quantitative advancement in heritage conservation and aim to:

- Strengthen the values people hold for the monument, financial and visitor management, and interpretation and communication.

- Enrich knowledge about the monument with the addition of economic feasibility studies, territory and tourism analysis, museum studies, etc.

- Involve from the beginning of the project multidisciplinary teams that include geographers, sociologists, museum specialists, economists, etc.

- Use more sophisticated dissemination and technical resources for communication

- Balance the high initial cost of these projects with the economic, cultural, and social benefits over the long term.

As mentioned previously one of the actions launched in these cultural restoration projects, apart from the physical restoration of the monument, is to promote the opening of on-site museums. These spaces emphasize additional values of the monument, the geographical and historical context and enable the public to better understand the significance of the building and the importance of preserving these values as part of the legacy of the site. Furthermore, this action aims at the improvement of the monument's cultural and visitor management. From the first experiences beginning with onsite displays and documentation of the restoration works to the more elaborated on-site museum the Foundation aims to facilitate and improve the access for the public to cultural heritage, both intellectual and physically. At the same time, this methodology contributes to a model that serves as an example for others, implementing and promoting a new approach to cultural and tourism management. The Caja Madrid Foundation has developed the concept of on-site museums through many projects. Each project has been observed and improved. This has strengthened public outreach and is being supported with the implementation of technical means that permit more sophisticated applications to improve the perception and the learning process of the public.

\section{THE CONCEPT OF "SALA DE FÁBRICA". THE CASE OF SAN MILLÁN DE YUSO}

Following this evolution, in 2005 the Caja Madrid Foundation, the Regional Government of La Rioja and the Religious Community of the Augustinian Recollects signed an agreement to promote the Cultural Restoration Project of the church of the $16^{\text {th }}$ century Monastery of San Millán de Yuso (La Rioja) that was included on the World Heritage List in 1997 as birthplace of the Spanish language. As in every project of the Caja Madrid Foundation, an ambitious Communication and Dissemination Plan was launched as part of the restoration project, aimed to introduce visitors and residents of the region to the concept of Cultural Heritage during the works and the importance of preserving the values and significance of this World Heritage Site [2]. During the work earlier Romanesque traces -building elements and foundations- were discovered. This extraordinary discovery confirmed the existence of the medieval church that until unearthed the only evidence was a few references in historical documents. When brought to light this discovery altered the project, but at the same time, gave an extraordinary opportunity to the multidisciplinary team to learn and study the origins and causes of the inception and development of this monastery since the $13^{\text {th }}$ century, and share their findings with the public (Figure 2). In addition, the historical and artistic research carried out during the project revealed the lack of context of a large amount of movable items belonging to the church, as well as the obsolescence of the explanations given by the guides that lead the public visits. Also, the integral restoration of the church, especially concerning the baroque chapels decorated with frescoes, paintings and retablos strengthen the richness of a cultural heritage that had never been opened to public before. Once the works were over, all these historic documents, studies, plans, photographs, surveys and remains from the excavations and results from the restorations works were carefully analyzed, selected and edited, in order to tell the history of the Monastery of San Millán de Yuso, its origins and evolution throughout the centuries and how this process has defined the site that the visitor observes today. For the Caja Madrid Foundation it was crucial to display and explain all this information on site, where the real context of the information is all around and the documentation can be easily identified and related to the site. With these premises a 
"Sala de Fábrica" was installed in the Monastery of San Millán using some of the chapels inside the church. In the framework of the Cultural Restoration Project this permanent on-site museum aimed to:

- Permit the access of the public to the ensemble of chapels next to the presbytery, with their function redefined after the restoration. The most important one, the Relics Chapel, has recovered the collection of reliquary heads that were previously exhibited in a different space of the monastery, completely undervalued and out of context ${ }^{2}$ (Figure 3).

- Improve the presentation of the rest of the church making the cultural and religious uses compatible. In this regard, new signs were placed in front of all the retablos, updating their content to the new information retrieved during the investigation.
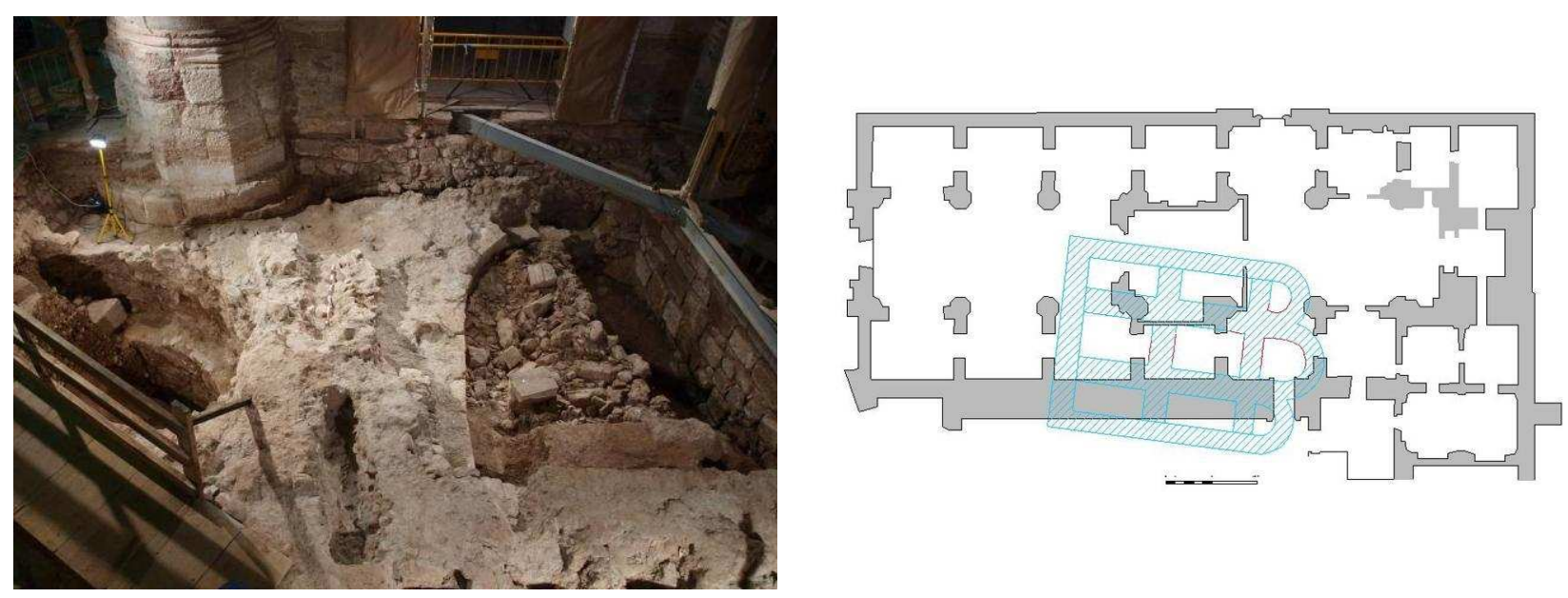

Figure 2. Discovery of the Romanesque church foundations in Yuso during the archaeological excavation
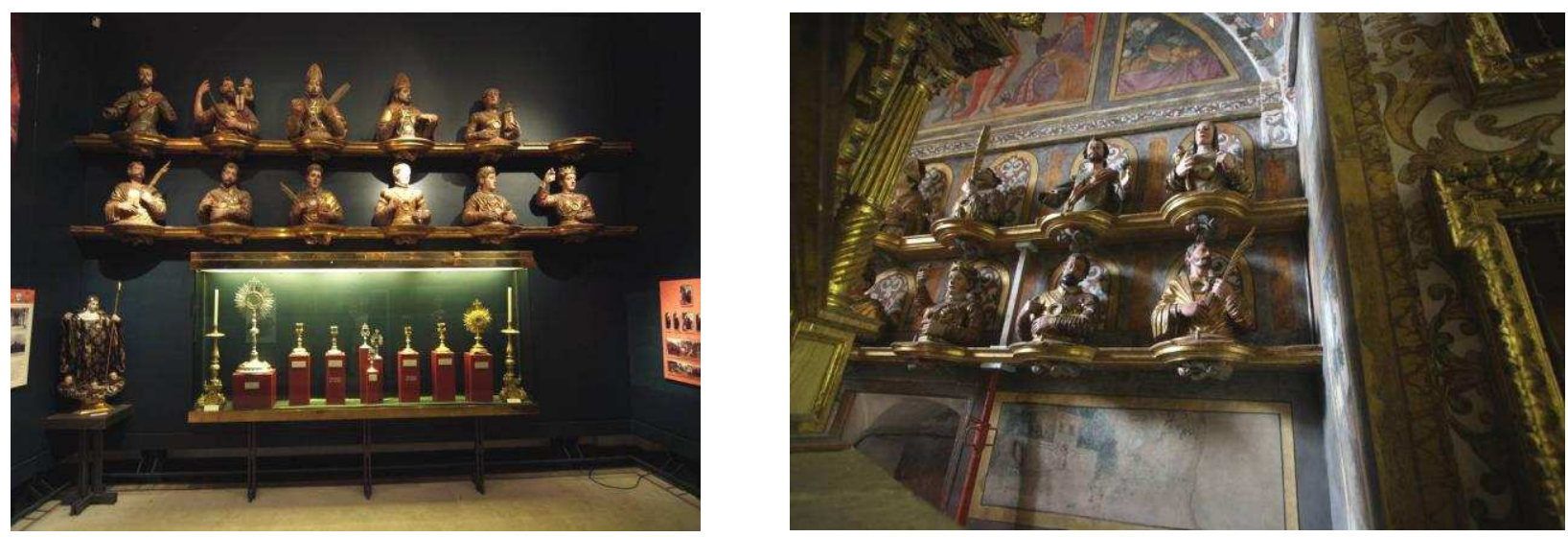

Figure 3. The reliquary heads collection exhibited out of context and back to their original location

- Open some of the restored chapels with no use into useful spaces that explain the historical and constructive evolution of the church and the Monastery. All the archaeological and historical information that was

\footnotetext{
${ }^{2}$ These reliquary heads as well as other movable objects had been placed out of context in spaces next to the church. Once these pieces were replaced in their original locations the space had to be restored. This is were the explanation of the medieval church was placed and the "Sala de Fábrica" concept was adopted for San Millán.
} 
collected by the professionals and experts during the 6-year project presented new discoveries and points of view about the constructive, artistic, religious and cultural development of the site (Figure 4).

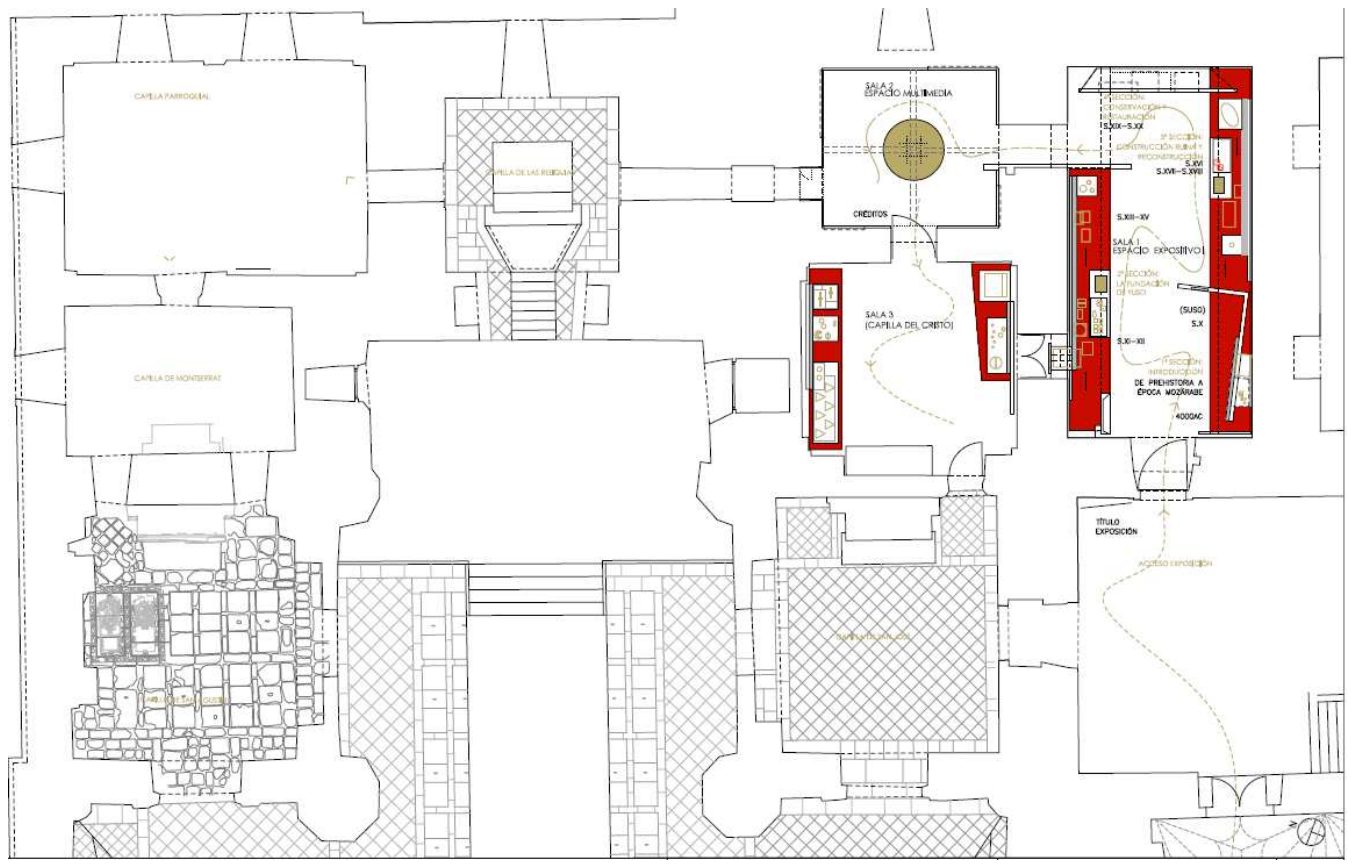

Figure 4. Detail of the "Sala de Fábrica" in San Millán de Yuso,

- Emphasize the importance of the archaeological discovery and give the opportunity to exhibit the remains found during the archaeological excavations that help to better understand the history of the Monastery (Figure $5)$.

During implementation, the information that had to be displayed was analyzed, adapted and edited to permit dissemination at different levels (scientific, general public) with exhibition resources adapted to the features of the monument. For this purpose hybrid products were the most useful for communication. Photogrammetric representations, 3D models, virtual visualization of the building geometry and multimedia applications permitted interactivity with the user. These products have demonstrated their usefulness to achieve this purpose, together with the monument itself, as well as the use of simple panels to display general information.

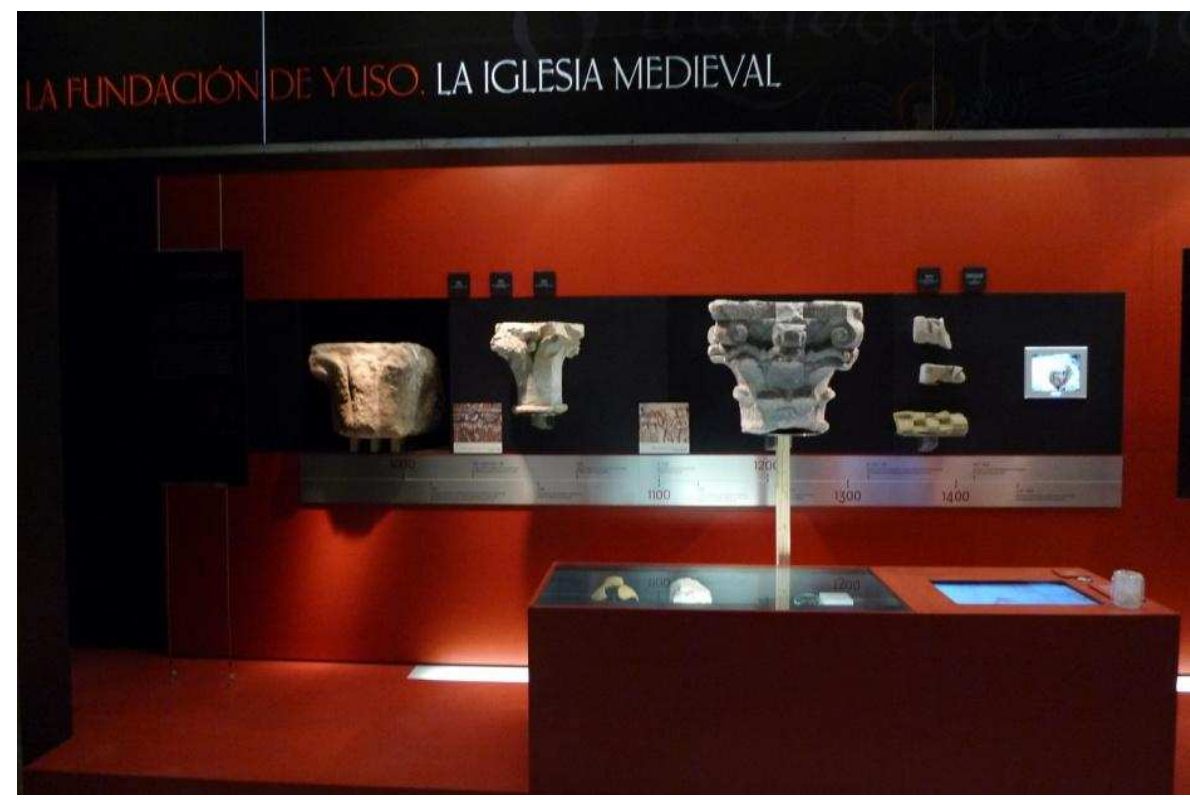

Figure 5. Exhibition of the archaeological remains in the "Sala de Fábrica" 
Apart from these products specially adapted for general public, all the technical documentation regarding the project is also displayed in special applications available on site. These applications permit more specific searches and consultations by professionals and experts or even public that request more detailed information about the work. From the preliminary studies developed during the investigation phase and the final technical reports of the restoration project to video productions and many kinds of graphic material -surveys, cartographies, analysis, 3D models -produced during the investigation and during the intervention that brought together a wide spectrum of specialists (Figure 6).
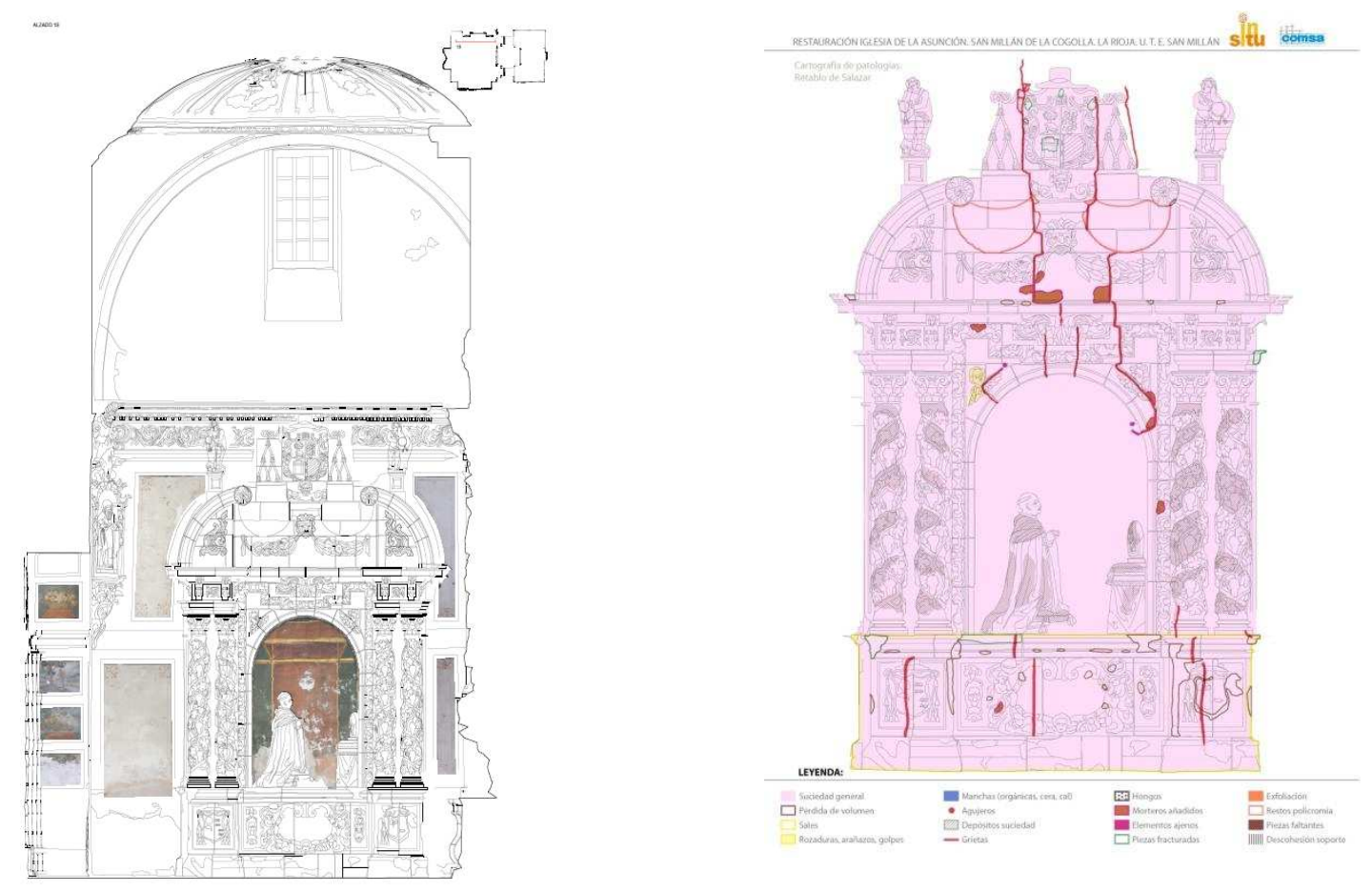

Figure 6. Photogrammetric survey of the Fray Benito de Salazar's stone retablo and its pathologies map

Contemporary to the implementation of the "Sala de Fábrica" and in the frame of the Cultural Restoration Project at large, an issue that has become crucial in this kind of project is the management model. This entails bringing together different institutions to work jointly, with interdisciplinary coordination between different professionals and integrating these new spaces into the previous visitor patterns of the monument. Last but not least, is the estimation of the cost for the institution responsible for the management of such an initiative in terms of employees, technical assistance, maintenance of hardware and software and general services to keep open to public this small but permanent infrastructure. In San Milan, the opening of this small on-site museum has obliged local managers and the Religious Community of the Augustinian Recollects to redefine certain aspects of their usual management of the Monastery, but the effort has already given very good results.

\section{A NEW "SALA DE FÁBRICA" COMING SOON FOR THE FAÇADE OF THE CATHEDRAL OF PAMPLONA}

Based on the positive experience at the Monastery of San Millán de Yuso, the Caja Madrid Foundation is now fully immersed in the preparation, coordination and management of a new "Sala de Fábrica" in the Cathedral of Pamplona (Navarra) that will open in September 2011. The project carried out over the last 4 years by the Archbishopric of Pamplona, the Regional Government of Navarra, the Town Hall of Pamplona, and the Caja Madrid Foundation, entailed 
the restoration of the $19^{\text {th }}$ century neoclassical façade [3] as well as the ensemble of eleven bells in the towers (Figure 7).

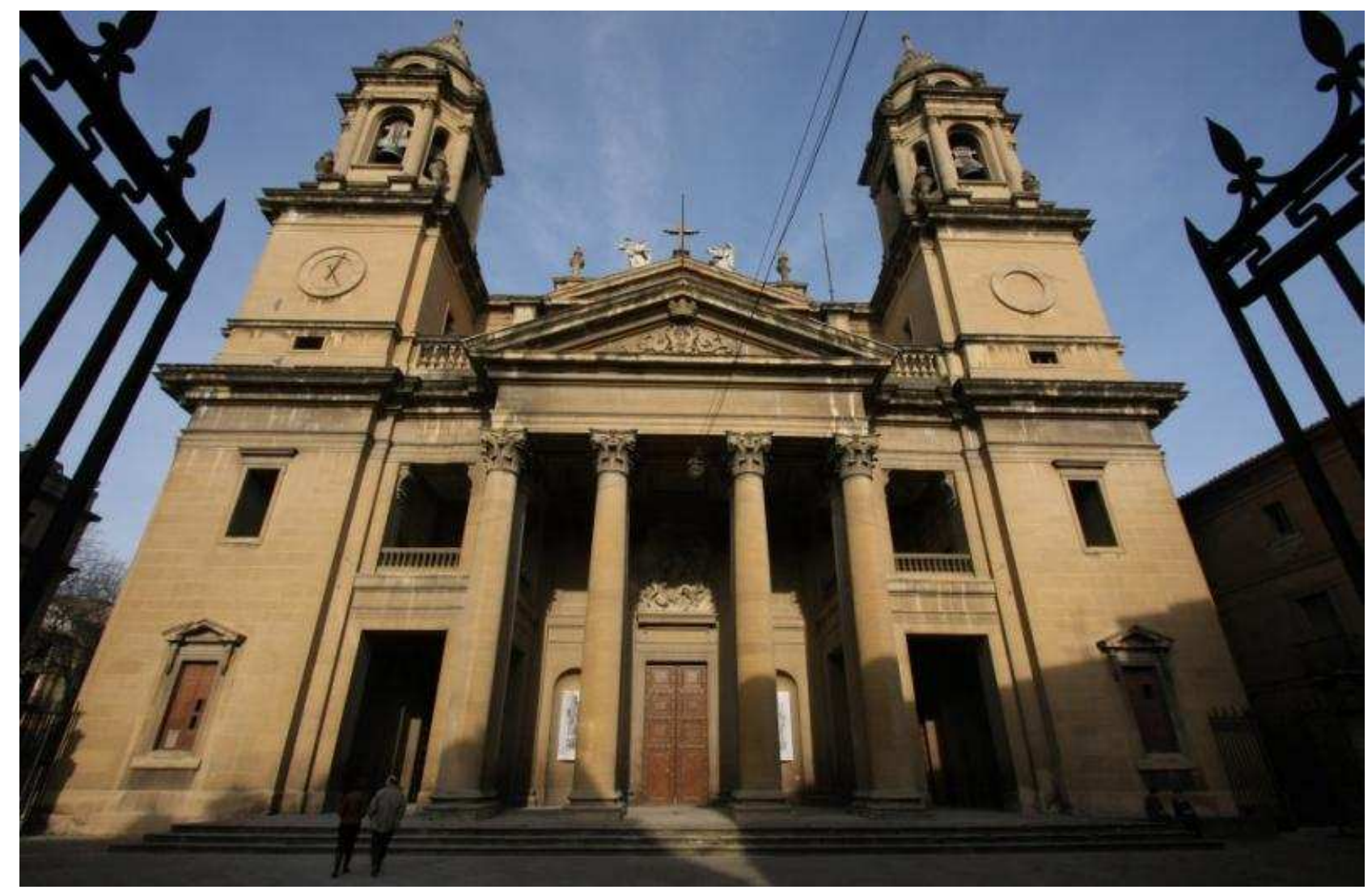

Figure 7. The façade of the Cathedral of Pamplona

In addition to these two main actions, the incorporation of a "Sala de Fábrica" was considered essential from the beginning. The intention was to recover the "Bell Ringer House" as a permanent on-site museum containing a documentation and dissemination programme similar to the one developed in San Millán de Yuso but enhancing certain aspects such as the importance of intangible heritage [4, 5]. This has provided interesting and challenging issues to document and transmit to the public, such as the exciting and unknown world of the bells and their ringers as well as their functional and cultural significance. Also, it was considered as a key issue to promote the maintenance and enhancement of this alive and sonorous cultural heritage that still surrounds everyday life in villages, towns and, less commonly, big cities [6]. Another important intangible aspect that was under study to be included in the on-site museum was the explanation and display of public discourse about the façade and its renovation in the $19^{\text {th }}$ century. This renovation divided the community between those defending the renowned architect Ventura Rodríguez (Fine Arts Royal Academy of San Fernando in Madrid) and those who considered the façade as an assault attached to the existing gothic building ${ }^{3}$. This division has continued until the present day. It is a goal of the "Sala de Fábrica" to capture and document this intangible aspect and to transmit the importance and relevance of this masterpiece of the neoclassical period in Spain. In addition to the intangible aspects, another important physical issue in this project has been the restoration of Ventura Rodríguez's original plan traced back to the $18^{\text {th }}$ century as well as other drawings related to the façade. All these paper and parchment materials that were abandoned and forgotten in the Cathedral Archive have been brought to light, restored and now ready to be exhibited appropriately in this on-site museum. Not only have the drawings been conserved but also the construction process has been given special attention in the "Sala de Fábrica": the explanation and exhibition of materials used, artifacts and engineering techniques, and operations carried out during the $19^{\text {th }}$ century work. A 3D computer model was created that explains the 18 year façade construction process. The architect's original worksite books were analyzed and used as the basis for this model. Finally, like in the case of San Millán de Yuso, all the information from the preliminary studies, project documents, photographic materials and final reports were included in the "Sala de Fábrica". Objects found during the works as well as pieces that had to be replaced

\footnotetext{
${ }^{3}$ The famous author Victor Hugo wrote about the façade, calling the towers "donkey ears" [7].
} 
because of their poor condition will also be exhibited. All of this will be explained through text, images, video and audio through multimedia applications permitting the users to deepen their knowledge

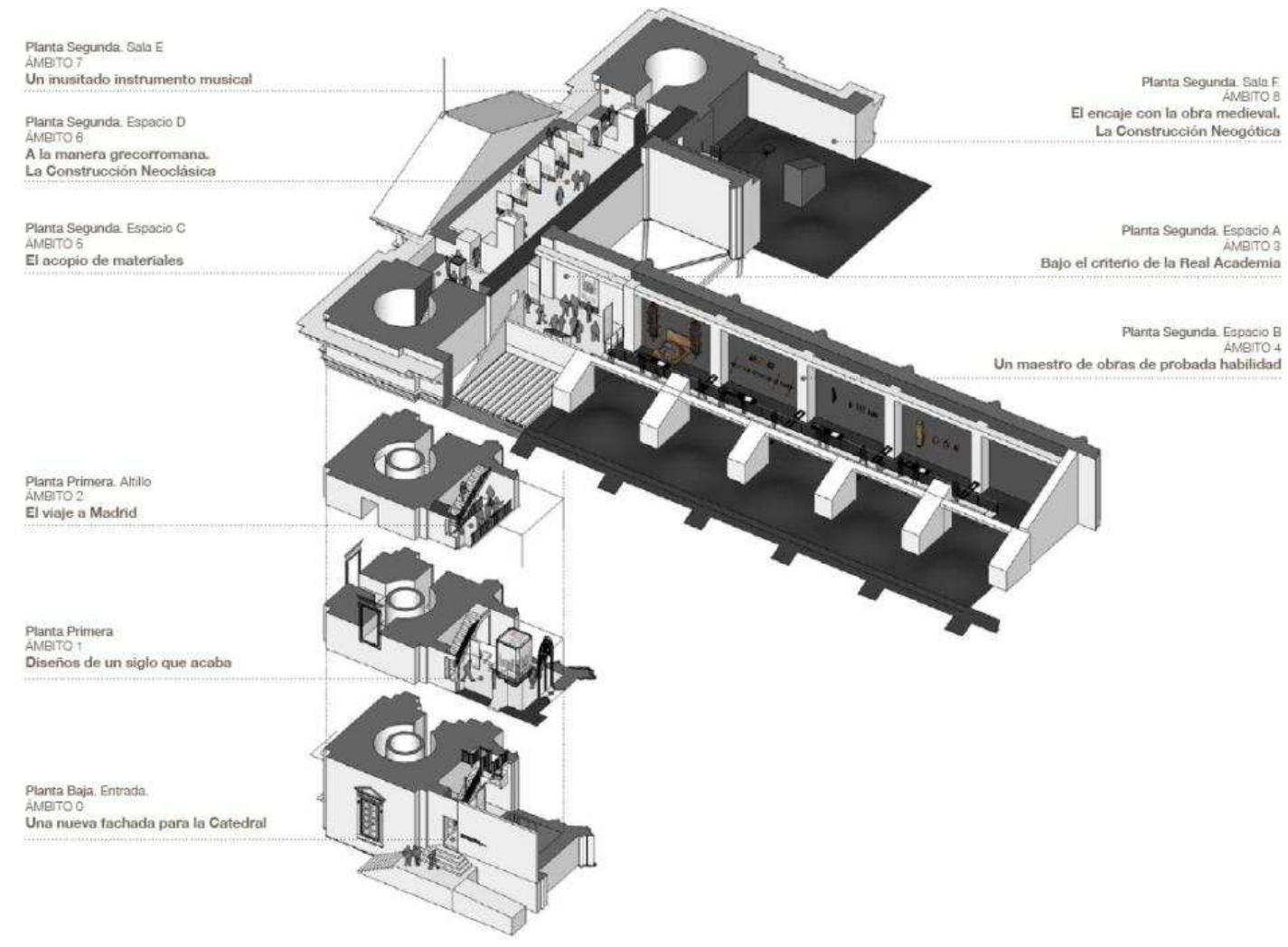

Figure 8. Axonometric model with the "Sala de Fábrica" distributed along the "Bell Ringer House"

With this "Sala de Fábrica" the Cathedral now has almost 300m2 of exhibit space dedicated to the façade and its tangible and intangible values, which have never been emphasized before. The Archbishopric was provided with a simple management plan to operate the "Sala de Fábrica", permit visits to both the façade and cathedral and employ the bells for liturgical use (Figure 8).

\section{CONCLUSIONS}

The creation of a "Sala de Fábrica" entails an important contribution to the management of tourism in cultural heritage sites but depends on individual circumstances, project limitations and budget constraints. The implementation of these "Salas de Fábrica" is an action not always foreseen in restoration projects as not all projects are meant to have such a space. But in any case, these spaces, in conclusion, help to:

- Enrich the cultural visit to the monument with the incorporation of new spaces that emphasize tangible and intangible values of the monument ${ }^{4}$. In these terms the public visit increases social and economic benefits to the monument and, consequently, to the city.

- Permits an updated interpretation of the monument on-site based on the multidisciplinary studies and projects carried out and the remains discovered.

- Offers a space to consult all the documentation regarding the cultural restoration project.

\footnotetext{
${ }^{4}$ This premise is included in the Spanish Constitution, article 44.1 [8]:'Los poderes públicos promoverán y tutelarán el acceso a la cultura, a la que todos tienen derecho': the right of every person to access culture, not only physically but also intellectually. In these terms, cultural heritage will always require intermediation and explanation.
} 


\section{REFERENCES}

[1] Tomaszewski, A., Simone, G. (Eds.): The Image of Heritage. Changing Perception, Permanent Responsibilities. Edizioni Polistampa, Firenze 2011.

[2] Morate, G., Almagro, A., Blanco, T., Andonegui, M. (2008): The Monastery of San Millán de Yuso (Spain): Transmitting the importance of preserving the significance of a World Heritage Site. Proceedings of the 16th ICOMOS General Assembly and International Symposium: 'Finding the spirit of place - between the tangible and the intangible', sept-oct 2008, Quebec, Canada. http://www.international.icomos.org/quebec2008/cd/toindex/77_pdf/77-1Ffb-282.pdf 2011-08-15.

[3] Lorda, J.: Fachada de la catedral de Pamplona: sus temas compositivos, Cuadernos de la Cátedra de Patrimonio y Arte Navarro (2006), núm.1, pp. 93-107.

[4] Blake, J.: UNESCO's 2003 Convention on Intangible Cultural Heritage. The implications of community involvement in safeguarding. Intangible Heritage - Key Issues in Cultural Heritage, (2009). pp 45-50.

[5] Patrimonio Cultural Inmaterial - El Texto de la Convención para la Salvaguardia UNESCO (2006) http://www.unesco.org/culture/ich/index.php?lg=es\&pg=00006, 2011-08-15.

[6] Llop i Bayo, F.: Campanas, campanarios y toques: la recuperación de un sonido perdido pp 44-51. ICCROM, 2003.

[7] Jusué Simonena, C.: Visión de viajeros sobre la catedral de Pamplona p. 483.

http://dspace.unav.es/dspace/bitstream/10171/4136/1/Visi\%C3\%B3n\%20de\%20viajeros\%20sobre\%201a\%20catedral\% 20de\%20Pamplona\%20LIBRO\%20CATEDRAL\%201-16.pdf, 2011-08-15.

[8] Constitución Española 1978: http://noticias.juridicas.com/base_datos/Admin/constitucion.t1.html, 2011-08-15.

Original research at the Archives of Pamplona and Archives of the Monastery of Yuso by the Project Teams. Unpublished. 